\title{
Shoot Girdling Improves Rooting Performance of Kalamata Olive Cuttings by Upregulating Carbohydrates, Polyamines and Phenolic Compounds
}

\author{
Nikoleta-Kleio Denaxa *D, Stavros N. Vemmos and Peter A. Roussos
}

check for updates

Citation: Denaxa, N.-K.; Vemmos, S.N.; Roussos, P.A. Shoot Girdling Improves Rooting Performance of Kalamata Olive Cuttings by Upregulating Carbohydrates, Polyamines and Phenolic Compounds. Agriculture 2021, 11, 71. https://doi.org/10.3390/agriculture 11010071

Received: 23 December 2020 Accepted: 13 January 2021 Published: 16 January 2021

Publisher's Note: MDPI stays neutral with regard to jurisdictional clai$\mathrm{ms}$ in published maps and institutional affiliations.

Copyright: (C) 2021 by the authors. Licensee MDPI, Basel, Switzerland. This article is an open access article distributed under the terms and conditions of the Creative Commons Attribution (CC BY) license (https:// creativecommons.org/licenses/by/ $4.0 /)$.
Laboratory of Pomology, Department of Crop Science, Agricultural University of Athens, 11855 Athens, Greece; svemmos@aua.gr (S.N.V.); roussosp@aua.gr (P.A.R.)

* Correspondence: nkdenaxa@gmail.com; Tel.: +30-210-529-4596

\begin{abstract}
Girdling (a ring of bark approximately $5 \mathrm{~mm}$ wide) was applied on olive mother plants to investigate its effect on the rooting ability of cuttings. Treatment was applied in autumn and in spring. The cuttings were then immersed for $5 \mathrm{~s}$ into $2000 \mathrm{mg} \mathrm{L}^{-1}$ indole-3-butyric acid (IBA) in a $45 \% v / v$ ethanolic solution. Thirty days after girdling, cuttings were taken from girdled and control shoots from the part just above the girdle zone (basal), as well as from the part right above (middle). The base of the cuttings was collected, and the concentration of polyamines, phenolic compounds and soluble carbohydrates was determined. Girdling enhanced the rooting performance of the cuttings, while autumn proved to be a better season for rooting compared to spring. Girdling positively affected the concentration of all the measured parameters. The main characteristics of autumn cuttings were the high levels of glucose, mannitol, free and total polyamines, hydroxytyrosol, tyrosol, verbascoside, oleuropein, quercetin and luteolin. The cuttings taken from the middle part of the girdled shoot exhibited high sucrose, glucose, mannitol, free polyamines, hydroxytyrosol, luteolin-7-glucoside, total phenols and flavanol concentrations. Nonetheless, further research is needed in order to draw conclusions on the overall efficiency of girdling on inducing rooting of olive cuttings.
\end{abstract}

Keywords: carbohydrates; Olea europaea; rhizogenesis; phenolics; polyamines

\section{Introduction}

The olive is one of the most ancient fruit tree species, and is traditionally cultivated in the Mediterranean basin with great socioeconomic impact for the countries in the region. Since 2000, there has been a remarkable rapid expansion of olive cultivation in countries such as Australia, China, Argentina, Chile and New Zealand. Therefore, great numbers of new olive trees are required for new olive orchards and for the replacement of the existing traditional ones.

Asexual propagation by leafy cuttings is the most efficient and economical method of olive propagation [1]. However, leafy cuttings of different olive cultivars exhibit differences in their rooting ability [2]. Therefore, they have been categorized into three groups, easy (100-66\% rooting), moderate $(66-33 \%$ rooting) and hard-to-root (33-0\% rooting) [3]. The differences in genotypes, the kind of hormone applied and its concentration, the rooting medium, the nutritional status of mother plants, and the phenological stage are some of the possible factors that affect the rooting ability in olive cuttings [4-7]. Furthermore, endogenous factors such as polyamines and phenolic compounds, as well as the interactions between them, may influence the primary triggers for root initiation [8]. Cristofori et al. [9] proposed that auxin in conjunction with phenolics, flavonoids and/or polyamines may increase the root promoting stimulus.

"Kalamata" is one of the most important Greek cultivars (cvs) worldwide, highly appreciated for the production of black table olives. The excellent fruit quality and the 
special morphological characteristics of the fruit and tree distinguish this $\mathrm{cv}$ from other table olive cvs and make it very desirable to customers. Unfortunately, leafy cuttings of Kalamata present a very low rooting ability $(0-5 \%)$ and thus it is characterized as a hard-to-root cv [3]. Earlier studies have shown that the exogenous applied auxins failed to promote rooting in Kalamata cuttings, or they had only a slight rooting effect $[3,10]$.

Girdling of the shoot phloem is a horticultural practice that blocks the downward translocation of carbohydrates, hormones, and other possible root-promoting factors $[4,11]$. The resulting series of physiological changes, such as the accumulation of various organic substances that occur above the ring, affect the hormonal balance of the shoot, thus promoting root initiation $[12,13]$. The positive effect of girdling on root initiation has usually been attributed to the increase in carbohydrate content in the part of the shoot above the girdle which is used as the cutting source $[4,12,14]$. However, the effect of girdling on carbohydrate concentration varies, depending on the size of branches, time of application, size of the girdle, as well as the kind of tree [15].

Basak et al. [11] found that girdling increased soluble sugar concentration and the rooting ability in mangrove trees. Additionally, girdling was found to be the most effective method for the rooting of cv. "Domat" olive cuttings [16]. However, Usta [16] only reported the effect of girdling on the rooting percentage of olive cuttings, without determining the concentrations and changes of any endogenous rooting co-factor during the early phases of rhizogenesis. On the other hand, Wilson [17] did not confirm any positive effect of girdling on rooting of Eucalyptus grandis Hill ex Maid. stem cuttings. That was also the case for the Rhododendron arboreum girdled cuttings [18]. Furthermore, the effect of girdling on endogenous polyamines and phenolic compounds and its relationship with root initiation has not been investigated in olive trees so far.

The objectives of this study were: (a) to assess the effect of shoot girdling of olive mother plants on the rooting potential of the leafy stem cuttings of the recalcitrant $\mathrm{cv}$ Kalamata; (b) to examine the changes in the concentration of biochemical factors in the cuttings' bases induced by shoot girdling; and (c) to review the relationship between girdling, changes in biochemical factors, and the rooting potential of the cuttings.

\section{Materials and Methods}

\subsection{Plant Material and Sampling}

The experiments were carried out at the orchard of the Agricultural University of Athens on 30-year-old olive trees (Olea europaea L.) cv Kalamata grown in the field. The mother plants were about $1.5 \mathrm{~m}$ in height (diameter at chest height approximately $24 \mathrm{~cm}$ ) and had been heavily pruned two years earlier, in order to induce the production of new juvenile shoots [1,4]. A ring of bark (phloem till cambium, without injuring the xylem) approximately $5 \mathrm{~mm}$ wide was removed from the base of the current year's shoots in late September (autumn) and of one-year-old shoots in late March (spring). Thirty days after girdling, the girdled shoots were cut immediately below the girdle and were collected, as well as the non-girdled shoots that served as controls. All the shoots were then divided into two parts, i.e., the basal part, just above the girdle zone, and the middle part (Figure 1). All cuttings were of approximately $12 \mathrm{~cm}$ in length and had four leaves. The base of each cutting (approximately $1 \mathrm{~cm}$ ) was immersed for $5 \mathrm{sec}$ in $2000 \mathrm{mg} \mathrm{L}^{-1}$ indole-3-butyric acid (IBA) in a $45 \% v / v$ aqueous solution of ethanol in a beaker and placed in a mist unit (using tap water) on plant plugs (Preforma Plug/240 M1413 Vecol, Jiffy, The Netherlands). In both seasons, the cuttings were misted for $20 \mathrm{sec}$ every $12 \mathrm{~min}$. During the November to January rooting period (autumn-winter), the air temperature ranged from 9.1 to $20.3^{\circ} \mathrm{C}$ and the rooting medium temperature from 18.5 to $21.5^{\circ} \mathrm{C}$, whereas from May to July (spring-summer), the air temperature ranged from 21.1 to $27.9^{\circ} \mathrm{C}$ and the rooting medium temperature was from 21.8 to $25.3^{\circ} \mathrm{C}$. 

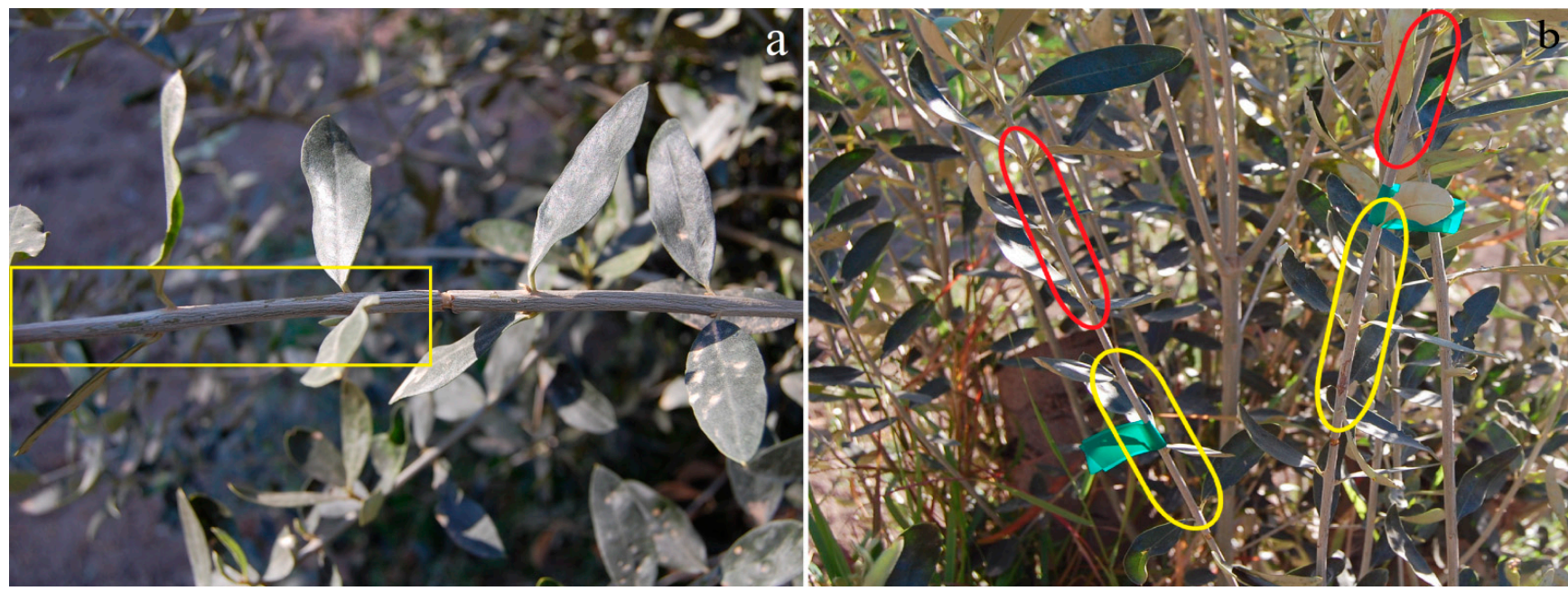

Figure 1. (a) Basal cutting that was cut just above the girdle zone, (b) basal cuttings (in the yellow circle) and middle cuttings (in the red circle).

The rooting experiment was arranged as a completely randomized design with four replications of 100 cuttings per replicate, a total of 400 cuttings per treatment (control basal cuttings, control middle cuttings, girdled basal cuttings and girdled middle cuttings). Three months after the experiment was established in the mist system, the percentage of rotten cuttings, as well as the cuttings with callus or roots, was evaluated.

Samples of 50 cutting bases (approximately $1 \mathrm{~cm}$ long under the node) per replication (four replicates-a total of 200 cuttings per treatment), were collected at day 0 (day of cutting excision and planting before auxin application). The samples were instantly frozen in dry ice and transferred to the laboratory. Then, the samples were lyophilized in a freeze dryer, ground into a fine powder by a centrifugal mill, and stored in a freezer $\left(-25^{\circ} \mathrm{C}\right)$ for further analysis.

\subsection{Biochemical Analyses}

\subsubsection{Carbohydrate Determination}

Carbohydrate extraction and determination was performed by the method described by [19]. Carbohydrate analysis was achieved through a Hamilton HC-75 cation exchange column, calcium form $\left(\mathrm{Ca}^{2+}\right)$ (Hamilton, Bonaduz, Switzerland), equilibrated at $80{ }^{\circ} \mathrm{C}$, with a Waters 510 isocratic pump at a flow rate of $0.6 \mathrm{~mL} \mathrm{~min}^{-1}$ of water. Four soluble sugars were detected in the base of olive cuttings: sucrose, glucose, fructose, and the sugar alcohol mannitol. Total sugar concentration was estimated by summing the concentrations of the individual sugars detected by HPLC.

Starch analysis was performed using an enzymatic method described by [20]. The absorbance of the red color produced was measured at $510 \mathrm{~nm}$ using a spectrophotometer (He $\lambda\llcorner\operatorname{sos} \gamma$, Unicam, UK). For all carbohydrate determinations, four analytical replicates per treatment were taken and each sample was analyzed in duplicate. Final concentrations were expressed as $\mathrm{mg} \mathrm{g}^{-1}$ of dry weight (d.w.).

\subsubsection{Polyamine Determination}

The extraction of polyamines (PAs) was performed according to the method described by [21], and the dansylation according to [22]. Separation, identification, and quantification (using 1.6 hexane diamine as the internal standard) was performed according to [21]. Four analytical replicates per treatment were performed, and each sample was analyzed in duplicate. Final concentrations were expressed as $\mathrm{mg} \mathrm{g}^{-1}$ d.w. Total PA concentration was estimated by summing the concentration of the individual PAs (total putrescine (Put), total spemidine (Spd) and total spermine (Spm)) detected by HPLC. 


\subsubsection{Extraction of Total Phenolic Compounds}

The extraction of phenolic compounds was achieved following the method described by [23]. The supernatant derived was assessed for HPLC phenolics, total phenols, total $o$-diphenols, total flavanols and total flavonoids, as described below.

Estimation of Endogenous Total Phenols

Total phenol content was determined by the Folin-Ciocalteu assay according to [23]. The intensity of blue color developed was recorded after $2 \mathrm{~h}$ at $760 \mathrm{~nm}$ on a spectrophotometer (He $\lambda$ ios $\gamma$, Unicam, UK). The results were expressed as milligrams of tannic acid equivalents per gram of d.w.

\section{Estimation of Endogenous Total o-Diphenols}

Total $o$-diphenol content determination was performed by the method described by [23]. The absorbance was measured after $15 \mathrm{~min}$ at $370 \mathrm{~nm}$ using a spectrophotometer (He $\lambda \cos \gamma$, Unicam). The results were expressed as mg of caffeic acid equivalents per gram of d.w.

\section{Estimation of Endogenous Total Flavonoids}

Total flavonoid content was determined using aluminum chloride $\left(\mathrm{AlCl}_{3}\right)$ according to [24]. The absorbance was measured at $510 \mathrm{~nm}$ on a spectrophotometer (He $\lambda$ ios $\gamma$, Unicam, UK). The results were expressed as $\mathrm{mg}$ of catechin equivalents per gram of d.w.

\section{Estimation of Endogenous Total Flavanols}

Total flavanol content was estimated using the $p$-dimethylaminocinnamaldehyde (DMACA) method according to [24]. The absorbance was measured at $640 \mathrm{~nm}$ on a spectrophotometer (He $\lambda$ ios $\gamma$, Unicam, UK) against a control prepared similarly without DMACA. The results were expressed as $\mathrm{mg}$ of catechin equivalents per gram of d.w.

\section{Estimation of HPLC Phenolic Compounds}

Analysis of individual phenolic compounds was performed according to the method described by [24]. Separation of phenolic compounds was performed by a Varian 9020 gradient HPLC system equipped with diode array detector [24]. The analysis was performed at $25^{\circ} \mathrm{C}$ on a Supelco column (Discovery HS C18, $25 \mathrm{~cm} \times 4.6 \mathrm{~mm}, 5 \mu \mathrm{m}$ ). The flow rate

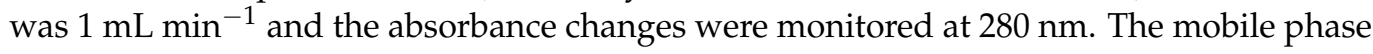
for chromatographic analysis consisted of solvents A and B, where solvent A contained water-glacial acetic acid (100:1 $v / v)$ and solvent B was methanol-glacial acetic acid (100:1 $v / v$ ). The solvent run comprised the following steps: isocratic $90 \%$ A for $5 \mathrm{~min}$; linear gradient from $90 \%$ A to $65 \%$ A in $55 \mathrm{~min}$; isocratic $65 \%$ A for $5 \mathrm{~min}$; linear gradient from $65 \% \mathrm{~A}$ to $55 \% \mathrm{~A}$ in $80 \mathrm{~min}$; linear gradient from $55 \% \mathrm{~A}$ to $20 \% \mathrm{~A}$ in $120 \mathrm{~min}$; equilibration of the column for $10 \mathrm{~min}$. Final concentrations were expressed as $\mathrm{mg} \mathrm{g}^{-1} \mathrm{~d}$.w.

\subsection{Statistical Analysis}

The statistical analysis was performed using JMP 7.0 statistical software (SAS Institute, Cary, NC, USA). Data for rooting, separately for each season, were analyzed using one-way ANOVA, with the factor being the treatment (control basal cuttings, control middle cuttings, girdle basal cuttings and girdle middle cuttings). Significant differences concerning the effects of interactions were detected using the Tukey's HSD test at $\alpha=0.05$, while those between pairs (effects of season, shoot part and treatment) using the Student's $t$-test at $\alpha=0.05$. Raw data of biochemical parameters were analyzed by three-way ANOVA, with the factors being the shoot girdling, the part of the shoot used (basal and middle), and the season of cutting collection (spring and autumn). Standard error was calculated from the residual variances of the multifactor ANOVA and used to determine significant differences among means when the factor effect was significant. 
Principal component analysis (PCA) based on all raw data derived in the present study was performed in order to describe the overall rooting performance of Kalamata cuttings by a short number of parameters and to find any possible relationship between girdling, the season of cutting collection, the part of the shoot used, the measured biochemical parameters and the rooting capacity of the cuttings.

\section{Results}

\subsection{Effect of Girdling, Part of Shoot and Season on the Rooting Ability of Olive Cuttings}

The rooting ability of Kalamata cuttings was significantly affected by girdling, as well as by the different parts used as cutting source and by the season (Table 1). The interaction between girdling and the part of the shoot used, the interaction between girdling and season, as well as the interaction between season and the part of the shoot used significantly affected, in most cases, the percentage of rotten cuttings, rooted cuttings, and callusing. The triple interaction also had a significant effect on the rooting potential of Kalamata cuttings (Table 2).

Table 1. The effects of shoot girdling, season and shoot part on rooting ability of olive cv. Kalamata cuttings.

\begin{tabular}{cccc}
\hline Factors & Rotten Cuttings (\%) & Callusing (\%) & Rooted Cuttings (\%) \\
\hline Treatment & $84 \pm 8 \mathrm{a}$ & $13 \pm 5 \mathrm{~b}$ & $3 \pm 2 \mathrm{~b}$ \\
Control & $65 \pm 7 \mathrm{~b}$ & $25 \pm 7 \mathrm{a}$ & $11 \pm 4 \mathrm{a}$ \\
Girdling & & & \\
Season & $67 \pm 8 \mathrm{~b}$ & $24 \pm 7 \mathrm{a}$ & $9 \pm 4 \mathrm{a}$ \\
Autumn & $82 \pm 9 \mathrm{a}$ & $13 \pm 5 \mathrm{~b}$ & $5 \mathrm{~b}$ \\
Spring & $80 \pm 7 \mathrm{a}$ & $16 \pm 6 \mathrm{a}$ & $5 \pm 3 \mathrm{~b}$ \\
Shoot part & $71 \pm 7 \mathrm{~b}$ & $21 \pm 6 \mathrm{a}$ & $9 \pm 4 \mathrm{a}$ \\
Basal & & & \\
Middle & & & \\
\hline
\end{tabular}

Means within the same column followed by the same lowercase letter do not differ significantly according to Student's $t$-test, at $\alpha=0.05$.

Table 2. The effects of interaction between shoot girdling, season and shoot part on rooting ability of olive cv. Kalamata cuttings.

\begin{tabular}{|c|c|c|c|}
\hline Factors & Rotten Cuttings (\%) & Callusing (\%) & Rooted Cuttings (\%) \\
\hline \multicolumn{4}{|l|}{ Season $\times$ Treatment } \\
\hline Autumn $\times$ Control & $79 \pm 8 b$ & $17 \pm 5 b$ & $4 \pm 3 c$ \\
\hline Autumn $\times$ Girdling & $55 \pm 6 c$ & $32 \pm 8 \mathrm{a}$ & $13 \pm 5 a$ \\
\hline Spring $\times$ Control & $87 \pm 9 \mathrm{a}$ & $9 \pm 4 c$ & $2 \pm 2 c$ \\
\hline Spring $\times$ Girdling & $74 \pm 9 \mathrm{~b}$ & $18 \pm 6 b$ & $8 \pm 4 \mathrm{~b}$ \\
\hline \multicolumn{4}{|l|}{ Season $\times$ Shoot part } \\
\hline Autumn $\times$ Basal cuttings & $71 \pm 8$ a & $22 \pm 6$ a & $7 \pm 3 \mathrm{a}$ \\
\hline Autumn $\times$ Middle cuttings & $63 \pm 7 \mathrm{a}$ & $26 \pm 8 \mathrm{a}$ & $11 \pm 5 \mathrm{a}$ \\
\hline Spring $\times$ Basal cuttings & $84 \pm 8 \mathrm{a}$ & $12 \pm 5 a$ & $4 \pm 3 a$ \\
\hline Spring $\times$ Middle cuttings & $79 \pm 10 \mathrm{a}$ & $14 \pm 6 a$ & $7 \pm 3 a$ \\
\hline \multicolumn{4}{|l|}{ Treatment $\times$ Shoot part } \\
\hline Control $\times$ Basal cuttings & $85 \pm 8$ a & $12 \pm 5 \mathrm{a}$ & $3 \pm 2 c$ \\
\hline Girdling $\times$ Basal cuttings & $70 \pm 7 \mathrm{a}$ & $22 \pm 6 \mathrm{a}$ & $8 \pm 4 \mathrm{~b}$ \\
\hline Control $\times$ Middle cuttings & $82 \pm 9 a$ & $14 \pm 4 \mathrm{a}$ & $4 \pm 3 c$ \\
\hline Girdling $\times$ Middle cuttings & $59 \pm 8 \mathrm{a}$ & $27 \pm 8 \mathrm{a}$ & $14 \pm 5 \mathrm{a}$ \\
\hline \multicolumn{4}{|l|}{ Season $\times$ Treatment $\times$ Shoot part } \\
\hline Spring $\times$ Control $\times$ Basal cuttings & $90 \pm 8 \mathrm{a}$ & $8 \pm 5 c$ & $2 \pm 2 c$ \\
\hline Spring $\times$ Control $\times$ Middle cuttings & $87 \pm 11 \mathrm{a}$ & $10 \pm 4 c$ & $3 \pm 3 c$ \\
\hline Spring $\times$ Girdling $\times$ Basal cuttings & $78 \pm 9 \mathrm{ab}$ & $17 \pm 5 \mathrm{bc}$ & $5 \pm 4 c$ \\
\hline Spring $\times$ Girdling $\times$ Middle cuttings & $70 \pm 9 \mathrm{bc}$ & $19 \pm 7 \mathrm{bc}$ & $11 \pm 4 b$ \\
\hline Autumn $\times$ Control $\times$ Basal cuttings & $80 \pm 10 \mathrm{ab}$ & $16 \pm 6 \mathrm{bc}$ & $4 \pm 3 c$ \\
\hline Autumn $\times$ Control $\times$ Middle cuttings & $77 \pm 8 \mathrm{ab}$ & $18 \pm 5 \mathrm{bc}$ & $5 \pm 3 c$ \\
\hline Autumn $\times$ Girdling $\times$ Basal cuttings & $62 \pm 6 \mathrm{~cd}$ & $28 \pm 8 \mathrm{ab}$ & $10 \pm 4 \mathrm{~b}$ \\
\hline Autumn $\times$ Girdling $\times$ Middle cuttings & $49 \pm 7 \mathrm{~d}$ & $35 \pm 10 \mathrm{a}$ & $16 \pm 7 \mathrm{a}$ \\
\hline
\end{tabular}

Means within the same column followed by the same lowercase letter do not differ significantly according to Tukey's HSD test at $\alpha=0.05$. 
Generally, the rooting ability was higher in autumn than in spring (Table 1). The middle part was the best cutting source considering the number of cuttings with roots (Table 1, Figure 2c). Autumn girdling significantly increased the rooting percentage of Kalamata cuttings to 16\% (cuttings from the middle part) and to 10\% (cuttings from the basal part) compared to the control (4-5\%) (Table 2). Similar results were found in spring, but only the cuttings from the middle part of the girdled shoots exhibited significantly higher rooting percentage (11\%) compared to the control (2\%) (Table 2). Girdling also had a positive effect on the callus formation in cuttings (Tables 1 and 2, Figure 2b), especially in autumn, while it reduced the percentage of rotten cuttings (Tables 1 and 2, Figure 2a).

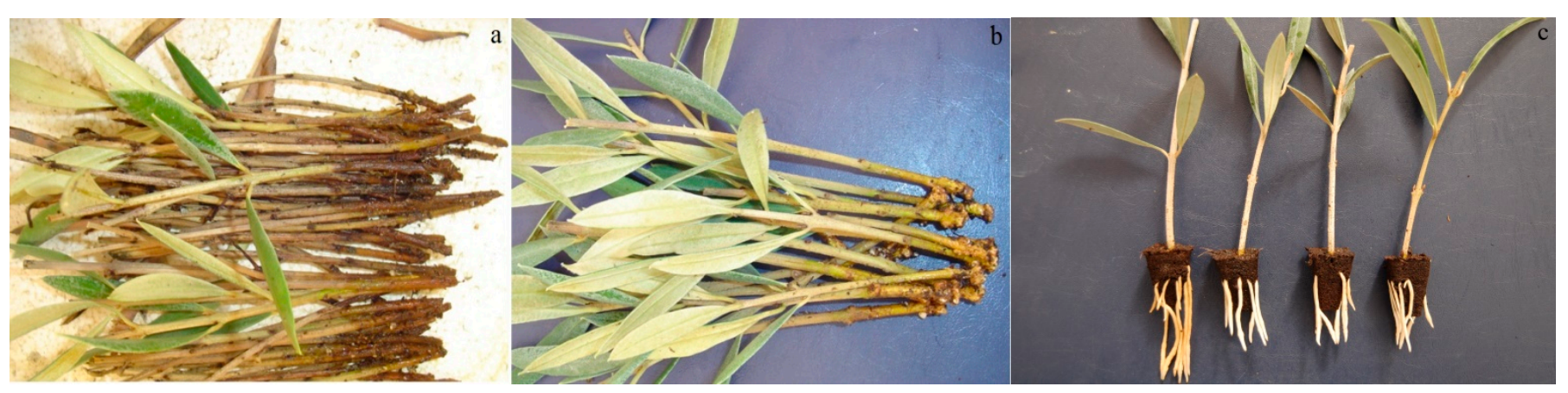

Figure 2. (a) Rotten control cuttings, (b) girdled cuttings with callus formation, (c) rooted girdled cuttings.

\subsection{Carbohydrate Concentration in Cuttings}

All three factors, i.e., girdling, the part of the shoot used, and the season, significantly influenced the concentrations of individual soluble sugars, total sugars, and starch (Table 3). The interaction between those factors, however, had, in most cases, little or no effect on the measured variables. There were significant differences between the different parts used as cutting sources concerning the concentration of individual and total soluble sugars, as well as starch, except for fructose (Figure 3, Table 3). The middle part was characterized by higher sucrose, glucose, mannitol, and total sugar concentrations, and by lower starch compared to the basal part of the shoot (Figure 3). Furthermore, cuttings taken in autumn exhibited high glucose, mannitol, and total sugar levels, while those taken in spring presented the highest concentration of sucrose, fructose, and starch (Figure 3). Girdling also positively affected the concentration of all the measured carbohydrates (Figure 3, Table 3).

Table 3. Probabilities of the effects of girdling, part of shoot used, and season on carbohydrate and polyamine (free and total) concentrations in cuttings.

\begin{tabular}{|c|c|c|c|c|c|c|c|c|c|c|c|c|c|}
\hline Factors & Suc & Gluc & Fruc & Man & $\begin{array}{c}\text { Total } \\
\text { Sugars }\end{array}$ & Starch & FPut & FSpd & FTotal & Put & Spd & Spm & Total \\
\hline Treatment $(\mathrm{T})$ & $* * *$ & $* * *$ & ** & $* * *$ & $* * *$ & $* * *$ & $* * *$ & ** & $* * *$ & $* * *$ & $* * *$ & $* * *$ & $* * *$ \\
\hline Shoot part $(\mathrm{P})$ & * & $* * *$ & ns & ** & $* * *$ & $* * *$ & $* * *$ & ** & $* * *$ & $* * *$ & $* * *$ & $* * *$ & $* * *$ \\
\hline Season $(S)$ & $* * *$ & $* * *$ & $* *$ & $* * *$ & $* * *$ & $* * *$ & $* * *$ & $* * *$ & $* * *$ & $* * *$ & $* * *$ & $* * *$ & $* * *$ \\
\hline $\mathrm{T} \times \mathrm{P}$ & ns & $* * *$ & ns & ns & ns & ns & $* * *$ & ns & $* *$ & $* * *$ & $* *$ & $* * *$ & $* * *$ \\
\hline $\mathrm{T} \times \mathrm{S}$ & ns & $* * *$ & ns & $* *$ & $* * *$ & $*$ & $* * *$ & $* *$ & $* *$ & $* * *$ & ** & $* * *$ & $* * *$ \\
\hline$P \times S$ & ns & ns & $*$ & ns & ns & ns & $* * *$ & ns & $* * *$ & ** & ns & ** & $* *$ \\
\hline $\mathrm{T} \times \mathrm{P} \times \mathrm{S}$ & ns & ns & $* *$ & ns & ns & ns & $* * *$ & ns & $*$ & $*$ & $* *$ & $* *$ & $* * *$ \\
\hline
\end{tabular}

${ }^{*}, p<0.05 ;{ }^{* *}, p<0.01 ; * * *, p<0.001 ; \mathrm{ns}$, not significant differences; $\times$, denotes interaction. Suc, Sucrose; Gluc, glucose; Fruc, fructose; Man, mannitol; FPut, free putrescine; FSpd, free spemidine; FTotal, free total polyamines; Put, putrescine, Spd, spermidine, Spm, spermine; Total, total polyamines. 

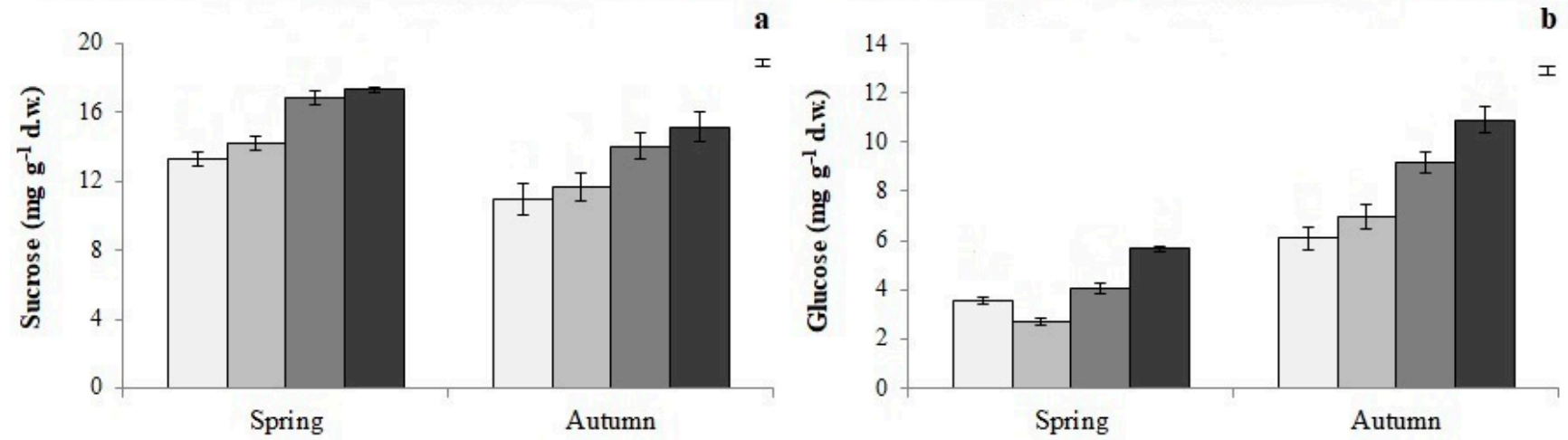

$\square$ Control basal $\square$ Control middle $\square$ Girdle basal $\square$ Girdle middle

$\square$ Control basal $\square$ Control middle $\square$ Girdle basal $\square$ Girdle middle
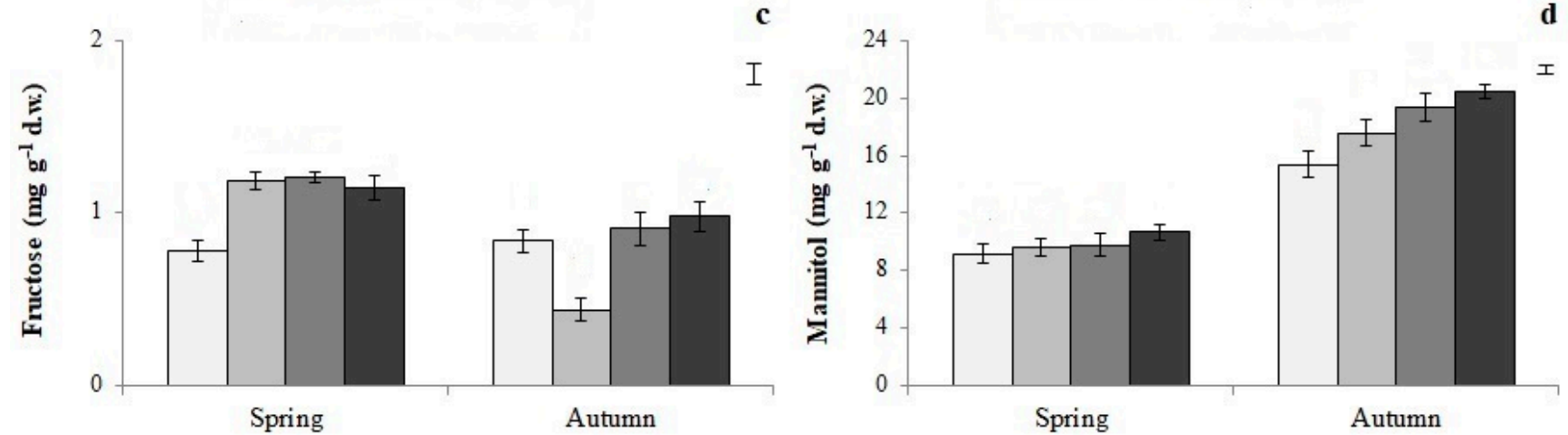

$\square$ Control basal $\square$ Control middle $\square$ Girdle basal $\square$ Girdle middle

$\square$ Control basal $\quad$ CControl middle $\square$ Girdle basal $\square$ Girdle middle
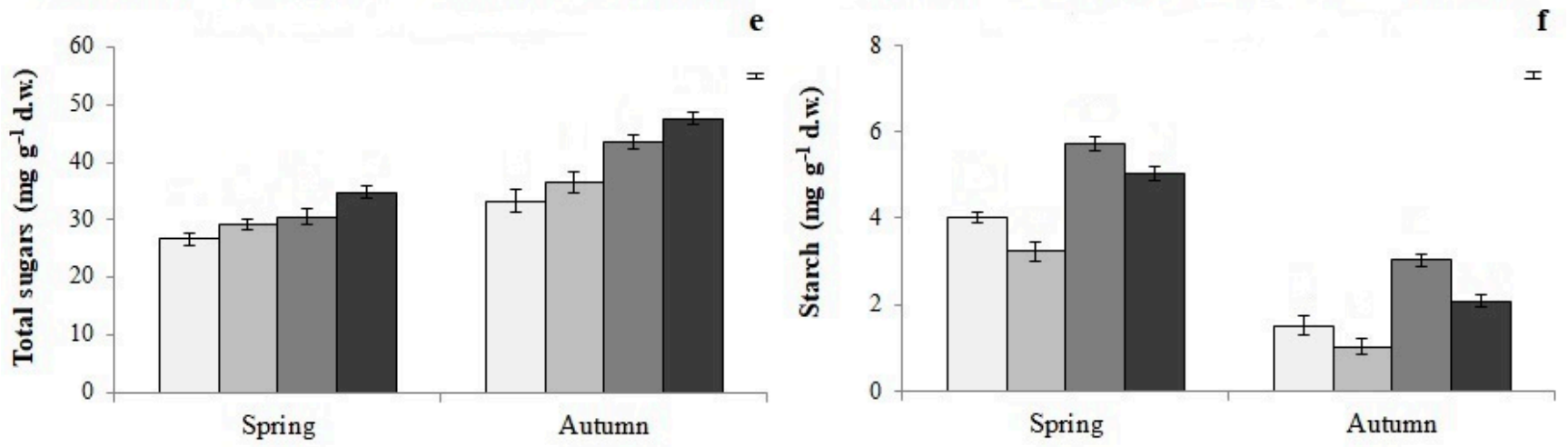

Figure 3. Effect of mother plants shoot girdling on cuttings' (a) Sucrose, (b) Glucose, (c) Fructose, (d) Mannitol, (e) Total sugars, (f) Starch concentrations in spring and autumn experimental seasons. The vertical bars at the right side of each diagram are the standard error of the multifactor ANOVA.

\subsection{Polyamine Concentration in Cuttings}

Girdling, as well as the part of shoots used and the season, significantly influenced the concentrations of all free and total PAs (Table 3). The interaction between the part of the shoot used, the season, and the treatment (control, girdling), also affected the measured PAs (total and free) in most cases. Total Put, total Spd, total Spm and total PA concentrations were significantly higher in cuttings taken in spring than those in autumn (Figure 4), while the opposite trend was identified for the concentrations of individual free and total free PAs (Figure 5). Girdling positively affected the concentrations of total Put, total Spd, total Spm, and their sum (total PAs) in both seasons (Figure 4, Table 3), while free Put, free Spd and total free PAs were higher in the cuttings taken from the girdled shoots in autumn (Figure 5). Moreover, cuttings taken from the basal part of the shoot were characterized by 
higher concentrations of total Put, total Spd and total Spm as well as of total PAs compared to the middle part (Figure 4). On the contrary, cuttings taken from the middle part exhibited significantly higher free Put, free Spd and total free PAs concentration, with this difference being more pronounced in autumn (Figure 5).

$\square$ Control basal $\square$ Control middle $\square$ Girdle basal $\square$ Girdle middle

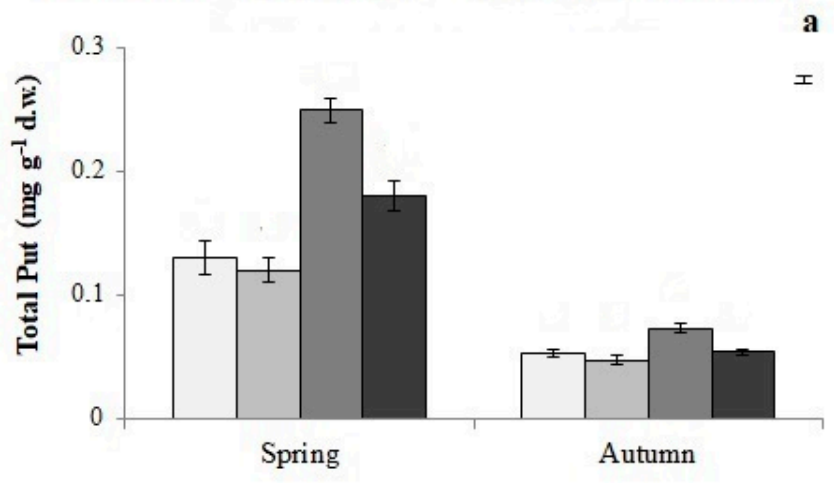

口Control basal $\square$ Control middle $\square$ Girdle basal $\square$ Girdle middle

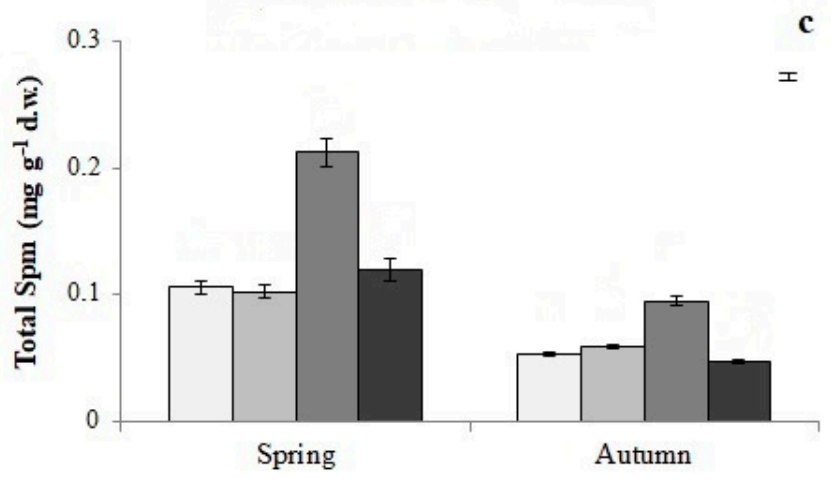

$\square$ Control basal $\square$ Control middle $\square$ Girdle basal $\square$ Girdle middle

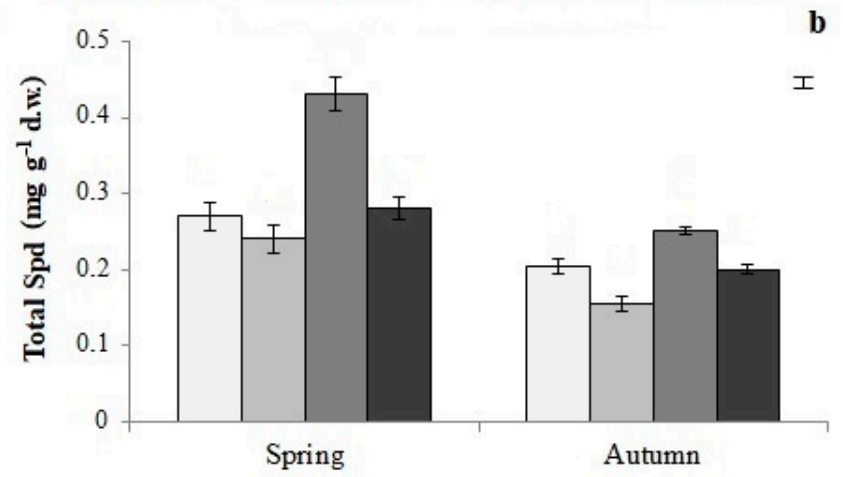

$\square$ Control basal $\square$ Control middle $\square$ Girdle basal $\square$ Girdle middle

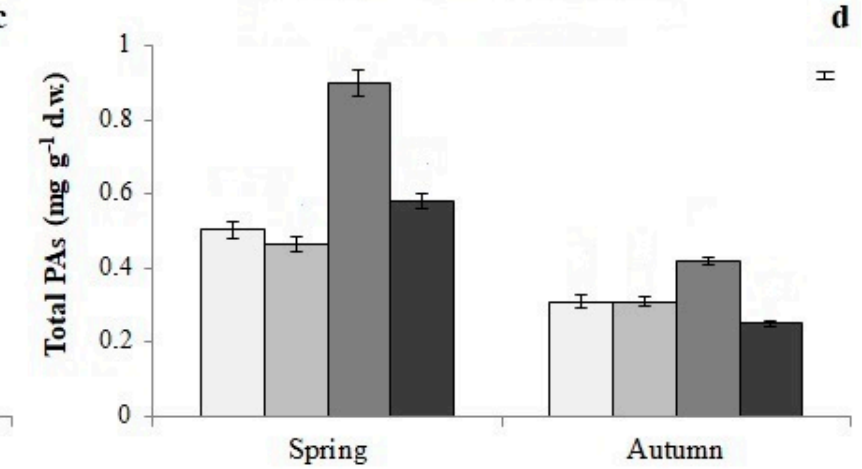

Figure 4. Effect of mother plants shoot girdling on cuttings' (a) Total Put, (b) Total Spd, (c) Total Spm, (d) Total PAs concentrations in spring and autumn experimental seasons. The vertical bars at the right side of each diagram are the standard error of the multifactor ANOVA.
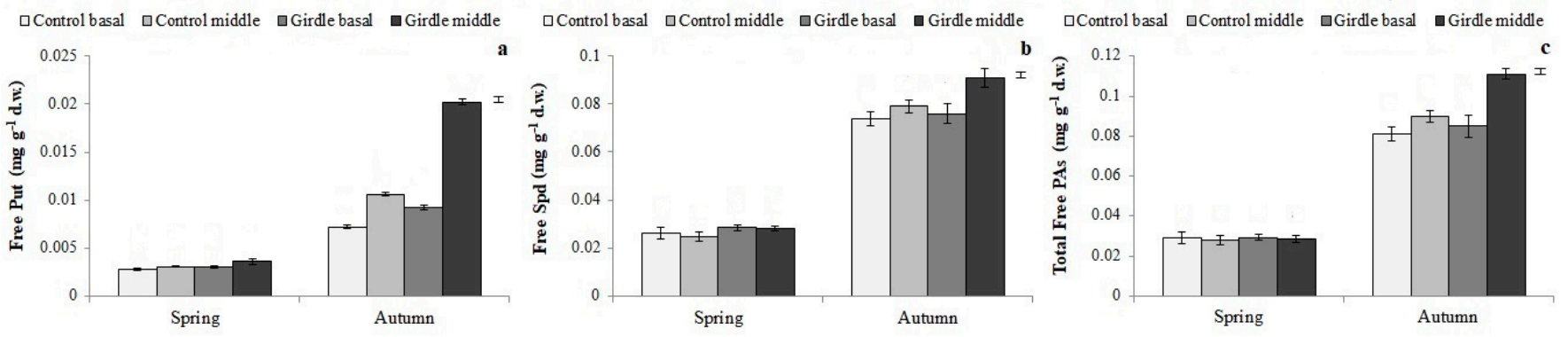

Figure 5. Effect of mother plants shoot girdling on cuttings' (a) Free Put, (b) Free Spd, (c) Total Free PAs concentrations in spring and autumn experimental seasons. The vertical bars at the right side of each diagram are the standard error of the multifactor ANOVA.

\subsection{Phenolic Compound Concentration in Cuttings}

Girdling, the part of the shoot used, and the season significantly influenced the concentrations of all total phenolic compounds (Table 4). The interaction between girdling and the part of the shoot used influenced the concentration of total phenols and total flavanols, and the interaction between girdling and the season affected the total o-diphenols and the total flavanols. Furthermore, the interaction between the part of the shoot used and the 
season affected all the measured variables except for the concentration of total $o$-diphenols. The triple interaction also had a significant effect on all total phenolic compounds apart from total flavonoids (Table 4).

Table 4. Probabilities of the effects of girdling, part of shoot used and season on total phenolic compound concentrations in cuttings.

\begin{tabular}{ccccc}
\hline Factors & Total Phenols & $\begin{array}{c}\text { Total } \\
\boldsymbol{o} \text {-Diphenols }\end{array}$ & $\begin{array}{c}\text { Total } \\
\text { Flavonoids }\end{array}$ & Total Flavanols \\
\hline Treatment (T) & $* * *$ & $* * *$ & $* * *$ & $* * *$ \\
Shoot part (P) & $* * *$ & $* * *$ & $* *$ & $* * *$ \\
Season $(\mathrm{S})$ & $* * * * * * *$ & $\mathrm{~ns}$ & $* * *$ \\
$\mathrm{~T} \times \mathrm{P}$ & $\mathrm{ns}$ & $\mathrm{ns}$ & $\mathrm{ns}$ & $* * *$ \\
$\mathrm{~T} \times \mathrm{S}$ & $\mathrm{ns}^{* * *}$ & $\mathrm{~ns}$ & $\mathrm{~ns}$ & $* * *$ \\
$\mathrm{P} \times \mathrm{S}$ & $* *$ & $* *$ & $\mathrm{~ns}$ & $* * *$ \\
$\mathrm{~T} \times \mathrm{P} \times \mathrm{S}$ & &
\end{tabular}

The concentrations of total phenols, total o-diphenols, total flavonoids, and total flavanols were significantly higher in cuttings taken from the girdled shoots than the non-girdled shoots (Figure 6). The middle part of the shoot was also characterized by higher concentrations of all the measured total phenolic compounds (Figure 6). Finally, total phenols, total $o$-diphenols, and total flavonoids exhibited much higher con-centrations in spring than in autumn (Figure 6a-c), while the opposite trend was observed for the concentration of total flavanols (Figure 6d).

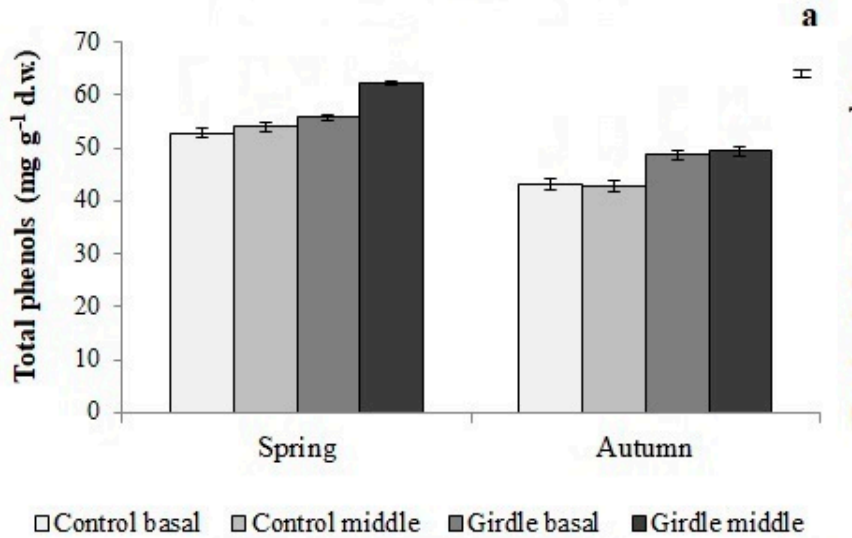

$\square$ Control basal $\square$ Control middle $\square$ Girdle basal $\square$ Girdle middle

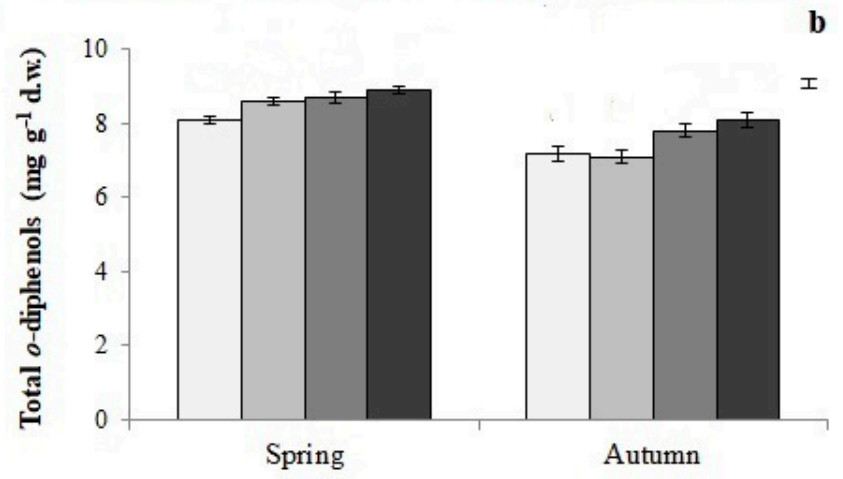

口Control basal $\square$ Control middle $\square$ Girdle basal $\square$ Girdle middle

$\square$ Control basal $\square$ Control middle $\square$ Girdle basal $\square$ Girdle middle
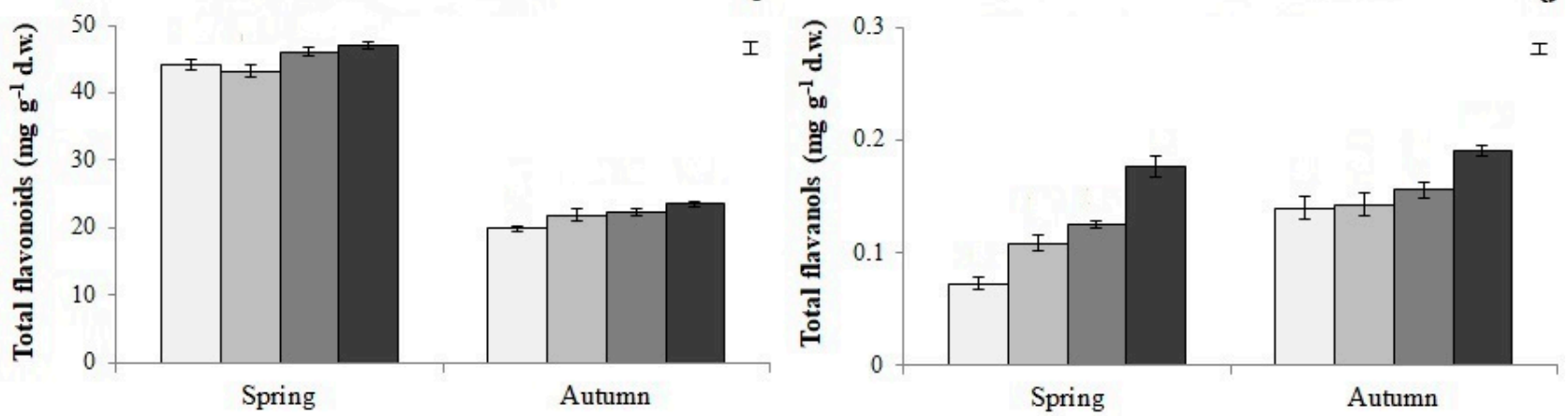

Figure 6. Effect of mother plants shoot girdling on cuttings' (a) Total phenols, (b) Total o-diphenols, (c) Total flavonoids, (d) Total flavanols concentrations in spring and autumn experimental seasons. The vertical bars at the right side of each diagram are the standard error of the multifactor ANOVA. 
The concentrations of all individual phenolic compounds were significantly affected by girdling and the season (Table 5). On the contrary, the part of the shoot used had no effect on the measured variables, except for luteon-7-glucoside and rutin. Furthermore, the interaction between the above factors had little or no effect on the measured variables. More specifically, the cuttings taken from the girdled shoots exhibited significantly higher levels of individual phenolic compounds compared to the controls (Figure 7). The different parts used as a cutting source only affected the concentration of luteolin-7-glucoside and rutin; the middle part was characterized by higher concentrations compared to the basal part of the shoot (Figure 7e,f). Furthermore, cuttings taken in autumn exhibited increased concentrations of hydroxytyrosol, tyrosol, verbascoside oleuropein, quercetin and luteolin (Figure $7 \mathrm{a}, \mathrm{b}, \mathrm{d}, \mathrm{g}, \mathrm{h}, \mathrm{i}$ ) and lower chlorogenic acid, luteolin-7-glucoside, and rutin levels (Figure $7 \mathrm{c}, \mathrm{e}, \mathrm{f}$ ) than those taken in spring.

\subsection{Principal Component Analysis (PCA)}

The PCA revealed four components with eigenvalues above 1.0, with the first two components (Table 6) together explaining $80 \%$ of the total variability. There was a clear distinction between the season of cutting collection (autumn and spring) (Figure 8b), as well as between girdled and non-girdled shoots of the mother plant that were used as the cutting source (Figure 8a). However, the middle part of the shoot used as a cuttings source presented common areas with the basal (Figure 8c).
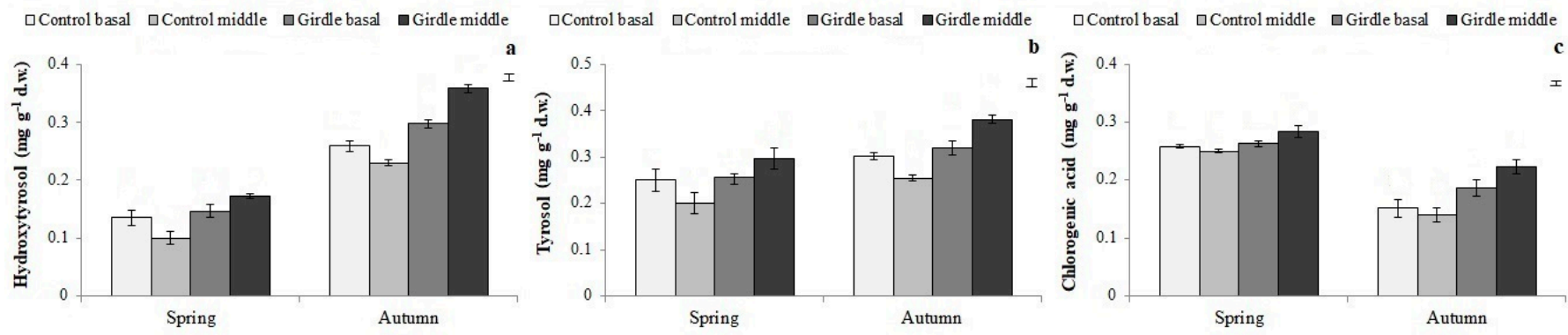

$\square$ Control basal $\square$ Control middle $\square$ Girdle basal $\square$ Girdle middle
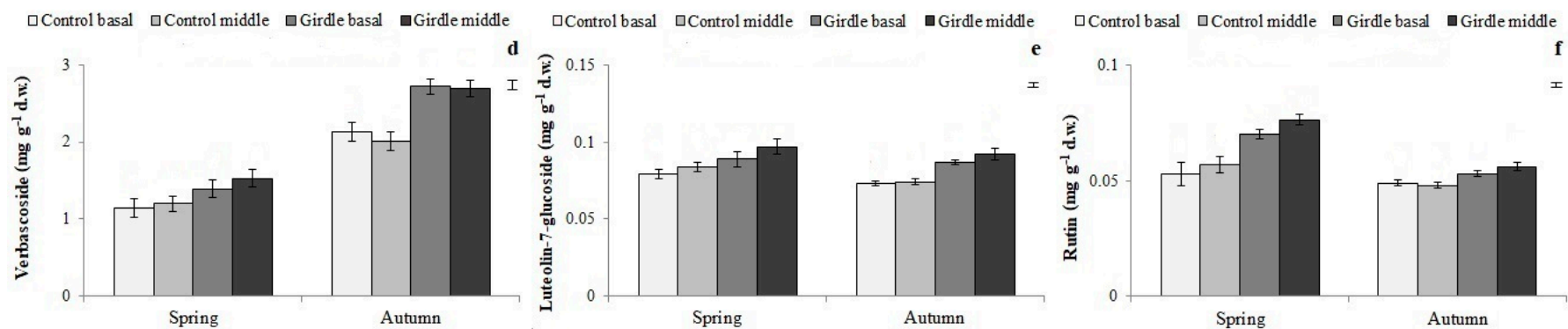

$\square$ Control basal $\quad$ CControl middle $\square$ Girdle basal $\square$ Girdle middle
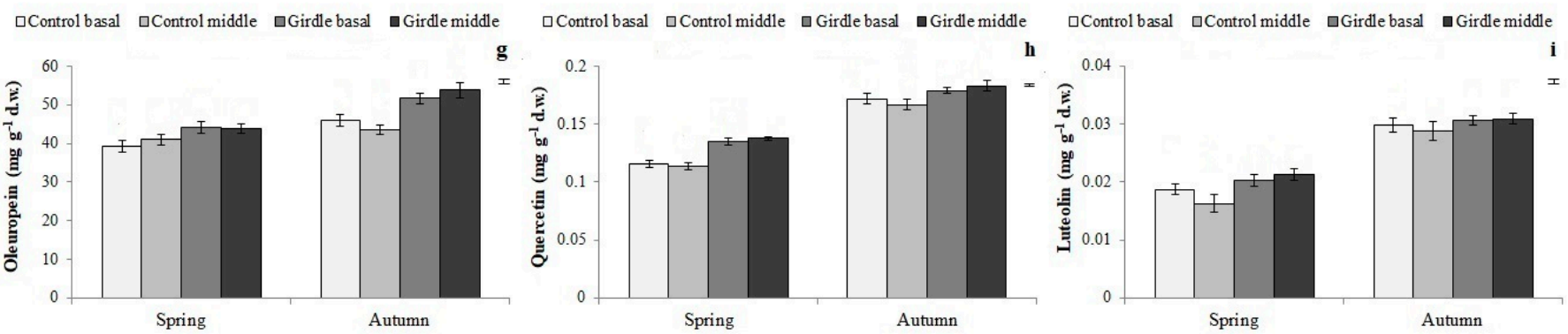

Figure 7. Effect of mother plants shoot girdling on cuttings' (a) Hydroxytyrosol, (b) language editing of the manuscript Tyrosol, (c) Chlorogenic acid, (d) Verbascoside, (e) Luteolin-7-glucoside, (f) Rutin, (g) Oleuropein, (h) Quercetin, (i) Luteolin concentrations in spring and autumn experimental seasons. The vertical bars at the right side of each diagram are the standard error of the multifactor ANOVA. 
Table 5. Probabilities of the effects of girdling, part of shoot used and season on individual phenolic compound concentrations in cuttings.

\begin{tabular}{|c|c|c|c|c|c|c|c|c|c|}
\hline Factors & HT & Tyr & CGA & Ver & Luteolin-7 & Rutin & OLE & Quer & Luteolin \\
\hline Treatment (T) & $* * *$ & $* * *$ & $* * *$ & $* * *$ & $* * *$ & $* * *$ & $* * *$ & $* * *$ & $* *$ \\
\hline Shoot part $(\mathrm{P})$ & ns & ns & ns & ns & $* *$ & $* *$ & ns & ns & ns \\
\hline Season (S) & $* * *$ & $* * *$ & $* * *$ & $* * *$ & $* *$ & $* * *$ & $* * *$ & $* * *$ & $* * *$ \\
\hline $\mathrm{T} \times \mathrm{P}$ & $* * *$ & $* * *$ & $* * *$ & ns & ns & ns & ns & $* *$ & ns \\
\hline $\mathrm{T} \times \mathrm{S}$ & $*$ & ns & $* * *$ & ns & ns & $* * *$ & $* *$ & $* * *$ & ns \\
\hline $\mathrm{P} \times \mathrm{S}$ & ns & ns & ns & ns & ns & ns & ns & ns & ns \\
\hline $\mathrm{T} \times \mathrm{P} \times \mathrm{S}$ & ns & ns & ns & ns & ns & ns & $*$ & ns & ns \\
\hline
\end{tabular}

${ }^{*}, p<0.05 ;{ }^{* *}, p<0.01 ; * * *, p<0.001 ;$ ns, not significant differences; $\times$, denotes interaction. HT, Hydroxytyrosol; Tyr, Tyrosol; CGA, Chlorogenic acid; Ver, Verbascoside; Luteolin-7, Luteolin-7-glucoside; OLE, Oleuropein; Quer, Quercetin.

Table 6. Component weights in principal component analysis based on the measured biochemical parameters in Kalamata cuttings.

\begin{tabular}{|c|c|c|c|c|}
\hline \multirow{2}{*}{ Factors } & \multicolumn{4}{|c|}{ Principal Components } \\
\hline & 1 & 2 & 3 & 4 \\
\hline Rooting & 0.089 & 0.308 & -0.202 & -0.014 \\
\hline Hydroxytyrosol & 0.227 & 0.142 & 0.002 & -0.082 \\
\hline Tyrosol & 0.161 & 0.220 & -0.118 & -0.144 \\
\hline Chlorogenic acid & -0.199 & 0.193 & -0.158 & 0.109 \\
\hline Verbascoside & 0.221 & 0.149 & 0.063 & -0.034 \\
\hline $\begin{array}{l}\text { Luteolin-7- } \\
\text { glucoside }\end{array}$ & -0.069 & 0.354 & -0.245 & 0.011 \\
\hline Rutin & -0.158 & 0.295 & -0.175 & -0.262 \\
\hline Oleuropein & 0.182 & 0.254 & 0.083 & 0.041 \\
\hline Quercetin & 0.233 & 0.105 & 0.068 & -0.189 \\
\hline Luteolin & 0.232 & 0.055 & 0.086 & -0.214 \\
\hline Free Put & 0.209 & 0.145 & -0.058 & 0.172 \\
\hline Free Spd & 0.246 & 0.029 & 0.058 & -0.026 \\
\hline Total free PAs & 0.245 & 0.041 & 0.044 & 0.026 \\
\hline Total Put & -0.212 & 0.152 & 0.143 & -0.262 \\
\hline Total Spd & -0.174 & 0.169 & 0.394 & -0.273 \\
\hline Total Spm & -0.190 & 0.168 & 0.353 & -0.218 \\
\hline Total PAs & -0.196 & 0.167 & 0.305 & -0.262 \\
\hline Sucrose & -0.127 & 0.241 & 0.230 & 0.429 \\
\hline Glucose & 0.271 & 0.159 & 0.201 & 0.172 \\
\hline Fructose & -0.099 & 0.191 & 0.001 & 0.267 \\
\hline Mannitol & 0.229 & 0.085 & 0.134 & 0.083 \\
\hline Total Sugars & 0.184 & 0.233 & 0.222 & 0.211 \\
\hline Starch & -0.207 & 0.070 & 0.223 & 0.335 \\
\hline Total phenols & -0.199 & 0.205 & -0.264 & 0.008 \\
\hline $\begin{array}{c}\text { Total } \\
\text { o-diphenols }\end{array}$ & -0.163 & 0.262 & -0.117 & 0.166 \\
\hline Total flavonoids & -0.243 & 0.059 & -0.088 & 0.051 \\
\hline Total flavanols & 0.144 & 0.281 & -0.255 & -0.140 \\
\hline
\end{tabular}

Girdling treatment was clearly distinguished in the scatterplot and was located on the positive side of principal component 2 , while the control was on the negative side (Figure 8a). The cuttings that were collected from the girdled mother shoots were characterized by high rooting percentages and high concentrations of tyrosol, luteolin-7-glycoside, rutin, oleuropein, total sugars, total o-diphenols, and total flavanols (Table 5). Furthermore, autumn was on the positive side of principal component 1 , and spring was on the negative side (Figure 8b). The main characteristics of autumn were the high concentrations of hydroxytyrosol, verbascoside, quercetin, luteolin, free Put, free Spd, total free PAs, glucose, and mannitol. On the other hand, spring was characterized by high chlorogenic acid and total flavonoid concentrations (Table 6). 

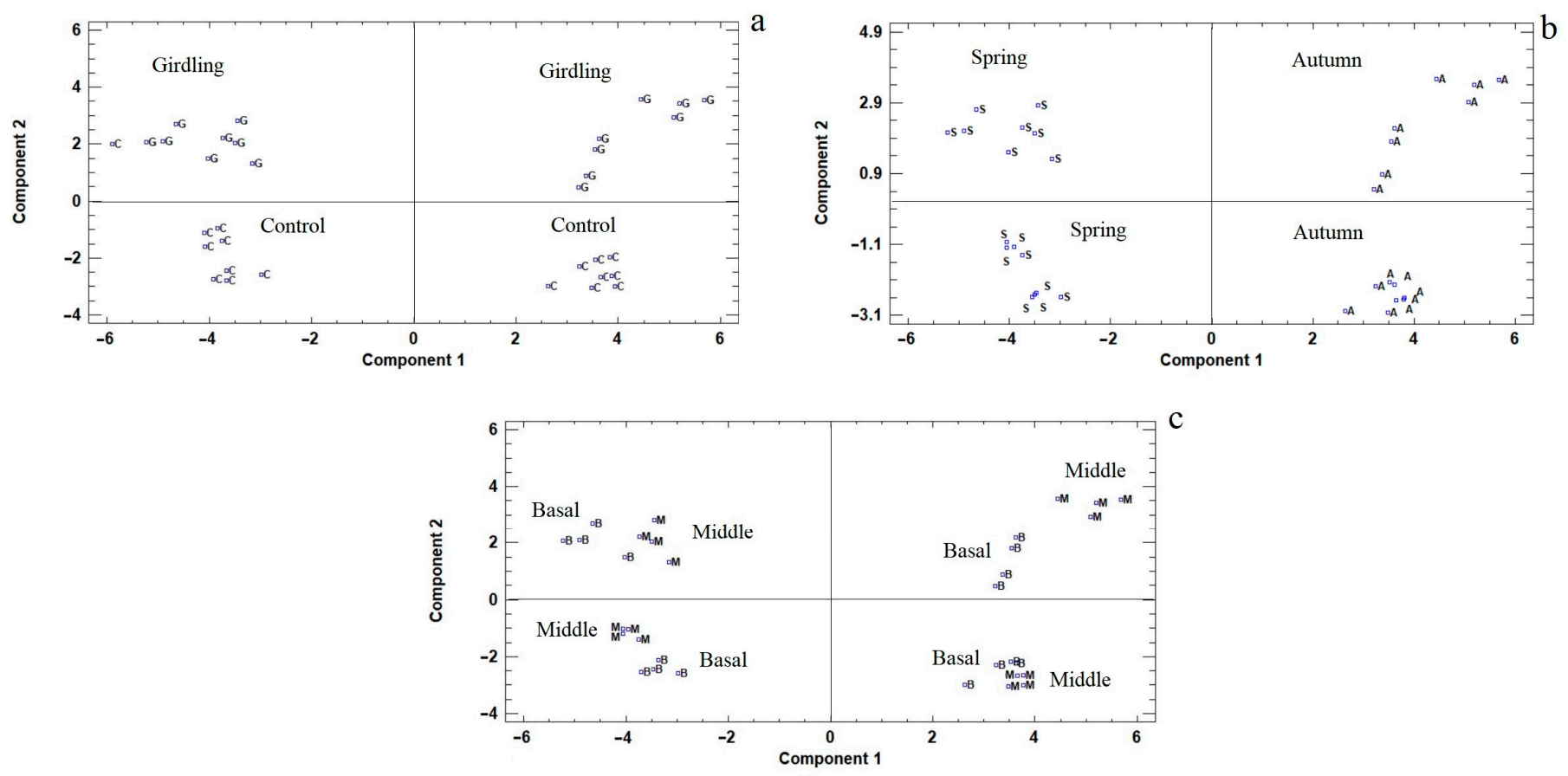

Figure 8. Pictorial presentation of the discriminant analysis results based on: (a) girdling (G, girdling; $\mathrm{C}$, control); (b) season of cutting's harvest (A, autumn; S, spring); and (c) part of the shoot used (B, basal part; M, middle part).

\section{Discussion}

Based on the results of the PCA analysis, it was clear that girdling had a distinguished effect on both the rooting performance of the cuttings as well as on the endogenous rooting co-factors. Girdling significantly increased the rooting performance of Kalamata cuttings independently of the season it was performed. Similar results on the effect of girdling on rooting ability of olive cuttings were also found by Usta [16]. Girdling has been found to promote rooting of semi-hardwood cuttings of Artocarpus heterophyllus Lam. [25], as well as of apple [26] and of mangrove species [11,27]. A number of biochemical parameters, such as carbohydrates, phenolic compounds and PAs, affected the root induction of Kalamata cuttings. Girdling stimulated the substantial accumulation of these rooting cofactors above the girdle zone, as has been reported by other researchers [11,12], and thus significant effects were exhibited on the root initiation of Kalamata cuttings. Girdling also increased callus formation and resulted in a reduction in rotten cuttings, effects that also might favor root formation.

According to Biswas [25], girdling blocks the basipetal movement of carbohydrates and other root-promoting factors and thus may positively affect root initiation. In the present study, high concentrations of soluble sugars, total sugars, and starch (Figure 3) were found in the girdled Kalamata cuttings, in accordance with the literature [11-14,28]. Furthermore, it is known that root formation relies on the utilization of soluble sugars [11], because carbohydrates are used as energy sources during rhizogenesis [1]. Carbohydrates can also improve the stimulatory effect of IBA by affecting auxin metabolism [29], and are structural constituents of root primordia, acting as carbon skeleton donors [30]. Thus, the increased carbohydrate concentration detected in the cuttings deriving from the girdled shoots might be partly responsible for the observed improvement of their rooting ability.

Apart from carbohydrates, girdling generally increased the concentration of total and individual phenolic compounds in both seasons (Figures 6 and 7, Tables 4 and 5). Kuokkanen et al. [31], as well as Roussos et al. [32], justified the accumulation of phenolic compounds in fruits from girdled scaffolds based on the hypothesis of growth differentiation balance. According to this theory, when carbohydrate biosynthesis exceeds the demand for growth, the excess carbon can be used for carbon-based secondary metabolites 
such as phenolic compounds [31]. In the present study, girdling enhanced carbohydrate accumulation above the girdle zone; therefore, it can be assumed that part of the excess carbohydrates might have served as substrates for the biosynthesis of phenolic compounds. Furthermore, Kubota et al. [33] and Khandaker et al. [34] attributed the increase in the phenolic concentration of the girdled shoots to the enhancement of the activity of phenylalanine ammonia lyase, the key enzyme in phenolic compound biosynthesis, which might also be the case here.

Tyrosol, luteolin-7-glucoside and rutin, as well as total $o$-diphenols, which are considered to act protectively against indole-3-acetic acid catabolism, protecting it from oxidation, during the induction and initiation phases $[24,35,36]$, were found, based on the PCA results (Table 6), to be related with the increased rooting performance of the girdled cuttings. These results indicate the possible positive effect of specific phenolic compounds on the adventitious rooting process. There are not much data in the literature regarding the effect of girdling on phenolic compounds concentration; therefore, the present data offer new insights into the effects of girdling on secondary metabolism and the accumulation of rooting co-factors.

The concentration of PAs was also affected by girdling (Figures 4 and 5, Table 3). The increased level of free PAs, and especially of free Put, has been correlated with root induction $[37,38]$, whereas bound PAs have been reported to have possible roles in rhizogenesis [39], which is not yet fully clarified. Therefore, based on the rooting results of the present study, it can be assumed that the accumulation of PAs in the cuttings deriving from girdled shoots, especially in their free form, may have enhanced cell division and morphogenesis [40-42], thus promoting cell differentiation into root primordia, under the effect of the exogenously applied auxin. Previous research in olive cuttings $[21,43,44]$ and other plant species [9] also indicates that the increased concentration of endogenous PAs promotes rooting and improves root quality.

The type of the cutting (basal or middle part), as well as the time of cutting collection, may also influence the rooting potential of Kalamata cuttings (Tables 1 and 2). Seasonal and even monthly or weekly changes in rooting performance have been reported in stone fruit rootstock cuttings [45], in Prunus cuttings [18,46], in Lobostemon fruticosus [47], and in many other species as well. These reports indicate that the rooting potential of the cuttings is significantly affected by the physiological state of the plant. According to Hartmann et al. [4] and Tsafouros et al. [45], the different ratio of endogenous root-promoting versus -inhibiting factors and/or the level of reserves changes with time, and therefore influences rooting performance.

Glucose, mannitol, and total sugars, independently of the cutting type, were higher in autumn than in spring, the period when the highest rooting percentage was recorded (Figure 3). A seasonal variation in the rooting ability, which was associated with changes in carbohydrate concentrations in olive cuttings, was also found in the previous studies of Denaxa et al. [19], Wiesman and Lavee [29], and Del Rio et al. [48], and in other plant species [30]. These results strengthen the significant role of both the season and carbohydrate pool on the rooting potential of cuttings.

Polyamines were also affected by the season; the levels of free PAs, which have a key role in cell division [40], were significantly higher in cuttings taken in autumn than in those in spring (Figures 4 and 5). Furthermore, in autumn, the concentration of individual phenolic compounds, except for chlorogenic acid, rutin and luteolin-7-glucoside, was increased compared to the control (Figure 7). Therefore, the increased rooting ability of autumn cuttings might be attributed to the increased endogenous concentrations of carbohydrates, free Pas, and specific phenolic compounds found at that time, compared to those of spring. The synergistic effect of the above rooting cofactors in the rooting potential of the stem cuttings has also been reported by Hartmann et al. [4].

As far as the part of the mother shoot used as the cutting source is concerned, the present results indicated that the middle part of girdled cuttings exhibited the highest rooting percentage (Tables 1 and 2). Similar results have been reported for a variety of 
plants, i.e., Lobostemon fruticosus [47], Santalum austrocaledonicum [49], and the rootstocks GF 677, Rootpac-R and Cadaman [45]. The concentration of the endogenous co-factors found in the present study may explain the different response of the two types of cuttings; the middle part was characterized by higher concentrations of sucrose, glucose, mannitol, free PAs, total phenolic compounds, luteolin-7-glucoside, and rutin (Figures 3-7). In agreement with the present results, Tombesi et al. [50] reported that the part of the mother shoot used for cuttings affected their rooting ability and is closely related to carbohydrate accumulation, in particular to soluble sugar content, at the cutting's base during the rooting process. This is also the case for PA, and phenolic compounds [24,36,51], because their high endogenous content has been correlated with high rooting percentages in olive cuttings [21] and in various other tree species [52,53].

Conclusively, the present study has shown that girdling significantly increased the rooting ability of olive cuttings by as much as $220 \%$ (from 5 to $16 \%$ in cuttings from the middle part, in autumn). Furthermore, girdling positively affected the concentration of soluble carbohydrates, free and total PAs, total phenolic compounds, as well as individual phenolic compounds. Nonetheless, further research is needed in order to draw conclusions on the overall efficiency of girdling on inducing olive cutting rooting, by using more hard-to-root olive cultivars as well as by performing girdling in different seasons. The accumulation of endogenous root-promoting substances above the girdled zone, such as carbohydrates, in combination with the increased concentrations of phenolic compounds and PAs, could be responsible for the recorded increase in the rooting potential of olive cuttings. However, according to Wiesman and Lavee [3] the economic threshold for cutting propagation is estimated to be around $20 \%$ of successful rooting. Thus, more research is necessary in order to further improve the root induction of olive cv Kalamata cuttings.

Author Contributions: Conceptualization, N.-K.D. and S.N.V.; methodology, N.-K.D., P.A.R. and S.N.V.; validation, N.-K.D.; formal analysis, N.-K.D.; investigation, N.-K.D.; resources, S.N.V. and P.A.R.; data curation, N.-K.D.; writing-Original draft preparation, N.-K.D. and P.A.R.; writingreview and editing, N.-K.D., P.A.R. and S.N.V.; visualization, N.-K.D. and P.A.R.; supervision, S.N.V. and P.A.R.; project administration, N.-K.D.; funding acquisition, N.-K.D., P.A.R. and S.N.V. All authors have read and agreed to the published version of the manuscript.

Funding: This research received no external funding.

Institutional Review Board Statement: Not applicable.

Informed Consent Statement: Not applicable.

Data Availability Statement: The data presented in this study are available on request from the corresponding author.

Acknowledgments: We would like to thank Mrs. Susan Coward for her English language editing services.

Conflicts of Interest: The authors declare no conflict of interest.

\section{References}

1. Fabbri, A.; Bartolini, G.; Lambardi, M.; Kailis, S.G. Olive Propagation Manual; Landlinks Press: Collingwood, Australia, 2004.

2. Fontanazza, G. Olivicoltura Intensiva Meccanizzata; Edagricole: Bologna, Italy, 1993; p. 103.

3. Wiesman, Z.; Lavee, S. Enhancement of stimulatory effects on rooting of olive cultivar stem cuttings. Sci. Hort. 1995, 62, 189-198. [CrossRef]

4. Hartmann, H.T.; Kester, D.E.; Davies, F.T.; Geneve, R.L. Plant Propagation Principles and Practices, 7th ed.; Prentice Hall: Saddle River, NJ, USA, 2002.

5. Sebastiani, L.; Tognetti, R. Growing season and hydrogen peroxide effects on root induction and development Olea europaea L. (cvs 'Frantoio' and 'Gentile di Larino') cuttings. Sci. Hort 2004, 100, 75-82. [CrossRef]

6. Avidan, B.; Lavee, S. Physiological aspects of the rooting ability of olive cultivars. Acta Hort. 1978, 79, 93-101. [CrossRef]

7. Sghir, S.; Belkoura, I.; Quazzani, N. Variability in the rooting ability of varieties of olive (Olea europaea L.). Olivae 2003, 96, 20-24.

8. Sankhla, N.; Upadhyaya, A. Polyamines and adventitious root formation. In Adventitious Root Formation in Cuttings; Davis, T.D., Haissig, B.E., Sankhla, N., Eds.; Dioscorides Press: Portland, OR, USA, 1988; pp. 202-213.

9. Cristofori, V.; Rouphael, Y.; Rugini, E. Collection time, cutting age, IBA and putrescine effects on root formation in Corylus avellana L. cuttings. Sci. Hort. 2010, 124, 189-194. [CrossRef] 
10. Denaxa, N.-K.; Vemmos, S.N.; Roussos, P.A.; Kostelenos, G. The effect of IBA, NAA and carbohydrates on rooting capacity of leafy cuttings in three olive cultivars (Olea europaea L.). Acta Hort. 2010, 924, 101-109. [CrossRef]

11. Basak, U.C.; Das, A.B.; Das, P. Metabolic changes during rooting in stem cuttings of five mangrove species. Plant. Growth Regul. 1995, 17, 141-148. [CrossRef]

12. Stoltz, L.; Hess, C. The effect of girdling upon root initiation: Carbohydrates and amino acids. Proc. Am. Soc. Hort. Sci. 1966, 89, 734-743.

13. Goldschmidt, E.E.; Huber, S.C. Regulation of photosynthesis by end-product accumulation in leaves of plants storing starch, sucrose and hexose sugars. Plant. Physiol. 1992, 99, 1443-1448. [CrossRef]

14. Aslmoshtaghi, E.; Shahsavar, A.R. Endogenous soluble sugars, starch contents and phenolic compounds in easy- and difficult-toroot olive cuttings. J. Biol. Environ. Sci. 2010, 49, 83-86.

15. Vemmos, S.N.; Papagiannopoulou, A.; Coward, S. Effects of shoot girdling on photosynthetic capacity, leaf carbohydrate, and bud abscission in pistachio (Pistacia vera L.). Photosynthetica 2012, 50, 35-48. [CrossRef]

16. Usta, S.S. The research on rooting ability of olive cuttings (Olea europaea L. cv. Domat). Acta Hort. 1999, 474, 63-66. [CrossRef]

17. Wilson, P.J. Contributions of the stem to rooting in Eucalyptus grandis Hill ex Maid. stem cuttings. J. Hort. Sci. Biotechnol. 1994, 69, 1009-1017. [CrossRef]

18. Negi, V.; Rana, S.; Hannah, P. Effect of auxins application on Rhododendron arboreum Smith pre-conditioned (girdled) stem cuttings. Environ. Ecol. 2017, 35, 3532-3534.

19. Denaxa, N.-K.; Vemmos, S.N.; Roussos, P.A. The role of endogenous carbohydrates and seasonal variation in rooting ability of cuttings of an easy and a hard to root olive cultivars (Olea europaea L.). Sci. Hort. 2012, 143, 19-28. [CrossRef]

20. Vemmos, S.N. Carbohydrate content of inflorescent buds of defruited and fruiting pistachio (Pistachia vera L) branches in relation to biennal bearing. J. Hort. Sci. Biotech. 1999, 74, 94-100. [CrossRef]

21. Denaxa, N.-K.; Roussos, P.A.; Vemmos, S.N. The possible role of polyamines to the recalcitrance of 'Kalamata' olive leafy cuttings to root. J. Plant. Growth Regul. 2014, 33, 579-589. [CrossRef]

22. Pedrol, N.; Tiburcio, A. Polyamines determination by TLC and HPLC. In Handbook of Plant Ecophysiology Techniques; Reigosa Roger, M.J., Ed.; Kluwer Academic Publishers: Amsterdam, The Netherlands, 2001; pp. 335-336.

23. Roussos, P.; Denaxa, N.-K.; Damvakaris, T. Strawberry fruit quality attributes after application of plant growth stimulating compounds. Sci. Hort. 2009, 119, 138-146. [CrossRef]

24. Denaxa, N.-K.; Roussos, P.A.; Vemmos, S.N. Assigning a role to the endogenous phenolic compounds on adventitious root formation of olive stem cuttings. J. Plant. Growth Regul. 2020, 39, 411-421. [CrossRef]

25. Biswas, M. Girdling, wounding, stem maturity and IBA effects on rooting of jackfruit stem cuttings. J. Haw. Pac. Agrl. 1995, 6, 19-25.

26. Delargy, J.A.; Wright, C.E. Root formation in cuttings of apple (cv. Bramley's seedling) in relation to ringbarking and to etiolation. New Phytol. 1978, 81, 117-127. [CrossRef]

27. Das, P.; Basak, U.C.; Das, A.B. Metabolic changes during rooting in pre-girdled stem cuttings and air-layers of Heritiera. Bot. Bull. Acad. Sin. 1997, 38, 91-95.

28. Evert, D.R.; Smittle, D.A. Limb girdling influences rooting survival, total sugar and starch of dormant hardwood peach cuttings. HortScience 1990, 25, 1224-1226. [CrossRef]

29. Wiesman, Z.; Lavee, S. Relationship of carbohydrate sources and indole-3-butyric acid in olive cuttings. Aust. J. Plant. Physiol. 1995, 22, 811-816. [CrossRef]

30. Yoo, Y.K.; Kim, K.S. Seasonal variation in rooting ability, plant hormones, carbohydrate, nitrogen, starch and soluble sugar contents in cuttings of White Forsythia (Abeliophyllum distichum Nakai). J. Kor. Soc. Hort. Sci. 1996, 37, 554-560.

31. Kuokkanen, K.; Julkunen-Tiitto, R.; Keinanen, M.; Niemela, P.; Tahvanainen, J. The effect of elevated $\mathrm{CO}_{2}$ and temperature on the secondary chemistry of Betula pendula seedlings. Trees-Struct. Funct. 2001, 15, 378-384. [CrossRef]

32. Roussos, P.A.; Tassis, A. Effects of girdling, nitrogen, zinc and auxin foliar spray applications on mandarin fruit "Nova" quality characteristics. Emir. J. Food Agric. 2011, 23, 431-439.

33. Kubota, N.; Nishiyama, N.; Shimamura, K. Effect of girdling lateral bearing branches on astringency and phenolic contents of peach fruits. J. Jpn. Soc. Hort. Sci. 1993, 62, 69-73. [CrossRef]

34. Khandaker, M.M.; Hossain, A.S.; Osman, N.; Boyce, A.N. Application of girdling for improved fruit retention, yield and fruit quality in Syzygium samarangense under field conditions. Int. J. Agric. Biol. 2011, 13, 18-24.

35. Curir, P.; Sulis, S.; Mariani, F.; van Sumere, C.F.; Marchesini, A.; Dolci, M. Influence of endogenous phenols on rootability of Chamaelaucium uncinatum Schauer stem cuttings. Sci. Hort. 1993, 55, 103-314. [CrossRef]

36. Osterc, G.; Štefančič, M.; Solar, A.; Štampar, F. Phenolic content in cuttings of two clones of hybrid chestnut (Castanea crenata $\mathrm{x}$ Castanea sativa) in the first days after cutting severance. Acta Agric. Scand. B 2008, 58, 162-168.

37. Kevers, C.; Hausman, J.F.; Gaspar, T. Involvement of putrescine and of its catabolic pathway in the induction of rooting of walnut shoots in vitro. In Biology of Root Formation and Development; Altman, A., Waisel, Y., Eds.; Plenum Press: New York, NY, USA, 1997; pp. 161-162.

38. Uribe, M.E.; Canal, M.J.; Fraga, M.; Ferrando, A.; Rios, D.; Noceda, C.; Altabella, T.; Tiburcio, A.F.; Rodrıguez, R. Polyamines in herbaceous and woody plants. Curr. Top. Plant Biol. 2004, 5, 53-62. 
39. Biondi, S.; Diaz, T.; Iglesias, I.; Gamberini, G.; Bagni, N. Polyamines and ethylene in relation to adventitious root for- mation in Prunus avium. Physiol. Plant. 1990, 78, 474-483. [CrossRef]

40. Neves, C.; Santos, H.; Vilas-Boas, L.; Amancio, S. Involvement of free and conjugated polyamines and free amino acids in the adventitious rooting of micropropagated cork oak and grapevine shoots. Plant. Physiol. Biochem. 2002, 40, 1071-1080. [CrossRef]

41. Tang, W.; Newton, R.J. Polyamines promote root elongation and growth by increasing root cell division in regenerated Virginia pine (Pinus virginiana Mill.) plantlets. Plant. Cell Rep. 2005, 24, 581-589. [CrossRef] [PubMed]

42. Mendes, A.F.S.; Cidade, L.C.; Otoni, W.C.; Soares-Filho, W.S.; Costa, M.G.C. Role of auxins, polyamines and ethylene in root formation and growth in sweet orange. Biol. Plant. 2011, 55, 375-378. [CrossRef]

43. Rugini, E.; Jacoboni, A.; Luppino, M. Role of basal shoot darkening and exogenous putrescine treatments on in vitro rooting and on endogenous polyamine changes in difficult-to-root woody species. Sci. Hort. 1993, 53, 63-72. [CrossRef]

44. Rugini, E.; Di Francesco, G.; Muganu, M.; Astolfi, S.; Caricato, G. The effects of polyamines and hydrogen peroxide on root formation in olive and the role of polyamines as an early marker for rooting ability. In Biology of Root Formation and Development; Altman, A., Waisel, Y., Eds.; Plenum Press: New York, NY, USA, 1997; pp. 65-73.

45. Tsafouros, A.; Frantzeskaki, A.; Assimakopoulou, A.; Roussos, P.A. Spatial and temporal changes of mineral nutrients and carbohydrates in cuttings of four stone fruit rootstocks and their contribution to rooting potential. Sci. Hort. 2019, 253, 227-240. [CrossRef]

46. Loreti, F.; Morini, S. Propagation techniques. In The Peach: Botany, Production and Uses; Layne, D.R., Bassi, D., Eds.; CAB International: Cambridge, UK, 2008; pp. 221-243.

47. Swarts, A.; Matsiliza-Mlathi, B.; Kleynhans, R. Rooting and survival of Lobostemon fruticosus (L) H. Buek stem cuttings as affected by season, media and cutting position. S. Afr. J. Bot. 2018, 119, 80-85. [CrossRef]

48. Del Rio, C.; Rallo, L.; Caballero, J.M. Effects of carbohydrate content on the seasonal rooting of vegetative and reproductive cuttings of olive. J. Hort. Sci. 1991, 66, 301-309. [CrossRef]

49. Tate, H.; Page, T. Cutting propagation of Santalum austrocaledonicum: The effect of genotype, cutting source, cutting size, propagation medium, IBA and irradiance. New For. 2018, 49, 551-570. [CrossRef]

50. Tombesi, S.; Palliotti, A.; Poni, S.; Farinelli, D. Influence of light and shoot development stage on leaf photosynthesis and carbohydrate status during the adventitious root formation in cuttings of Corylus avellana L. Front. Plant. Sci. 2015, 6, 973. [CrossRef] [PubMed]

51. Trobec, M.; Štampar, F.; Veberič, R.; Osterc, G. Fluctuations of different endogenous phenolic compounds and cinnamic acid in the first days of the rooting process of cherry rootstock 'GiSelA 5' leafy cuttings. J. Plant. Physiol. 2005, 162, 589-597. [CrossRef] [PubMed]

52. Hausman, J.F.; Keversa, C.; Gaspara, T. Auxin-polyamine interaction in the control of the rooting inductive phase of poplar shoots in vitro. Plant. Sci. 1995, 110, 63-71. [CrossRef]

53. Bartolini, G.; Toponi, M.A.; Di Monte, G. Variations in free polyamines and their effect on adventitious rooting of peach cuttings. J. Hort. Sci. Biotechnol. 2008, 83, 120-124. [CrossRef] 